\title{
The Evolution of Beliefs and Opinions on Matters related to Marriage and Sexual Behaviour among French-speaking Catholic Quebecers and English-speaking Protestant Ontarians
}

\section{Benoît Laplante \\ Caia Miller, ${ }^{\dagger}$}

Institut national de la recherche scientifique

Université du Québec

Montréal, Québec, Canada

\section{Paskall Malherbe}

Université Marc Bloch

Strasbourg, France

\begin{abstract}
The authors argue that the important changes in behaviour related to family and sexual life that were seen in Quebec during the second half of the 20th century are a consequence of a major transformation of the foundation of the normative system shared by the members of Quebec's main socio-religious group, Frenchspeaking Catholics. Using data from Gallup polls, the authors compare the evolution of the opinions of French-speaking Quebec Catholics and Englishspeaking Ontario Protestants on matters related to sexual and family behaviour from the 1950s to the beginning of the 2000s. The general result is that the evolution of the differences between the two groups is compatible with the hypothesis.
\end{abstract}

Key Words: Canada, Quebec, norms, second demographic transition 
The Evolution of Beliefs and Opinions as Matters related to Marriage and Sexual Behaviour among French-speaking Catholic Quebecers and English-speaking Protestant Ontarions

\section{Résumé}

Les auteurs proposent d'expliquer les importants changements qui se sont produits, dans le Québec de la deuxième moitié du $20^{\mathrm{e}}$ siècle, dans les comportements liés à la famille et à la vie sexuelle par la transformation du système normatif des membres de son principal groupe socio-religieux, les francophones catholiques. À partir des données de sondages Gallup, ils comparent l'évolution des opinions des francophones catholiques du Québec et des anglophones protestants de l'Ontario sur des questions liées à la famille et au comportement sexuel et de famille des années 1950 à 2000. L'évolution des différences entre les deux groupes est compatible avec l'hypothèse.

Mots-clés: le Canada; le Québec; les normes; la deuxième transition démographique

\section{Introduction}

The strength of the rise of cohabitation in Quebec and the related strong decline in marriage have attracted the interest of some demographers who have documented these phenomena, but none of these researchers has to date given a satisfactory explanation of the phenomena. This transformation of Quebecers' behaviour has been related to the second demographic transition (van de Kaa, 1987), but there is no real explanation of why, if this is the case, Quebec "lagged" behind the rest of Canada on this path until roughly the end of the 1960s, and then became a "forerunner," as Le Bourdais and Marcil-Gratton (1996) put it.

In their study of the early life transitions of Canadian women, Ravanera, Rajulton and Burch (1998) interpreted Quebec women's atypical behaviour as "a distinctive mixture of Gallic sophistication and modernity with lingering traces of a very conservative brand of Catholicism," which alludes to some form of normative distinctiveness but hardly qualifies as a real explanation. In his study of cohabitation in Canada, Wu (2000) leaves largely unanalyzed the difference between Quebec and the rest of Canada and, although he describes changes over time in the incidence of cohabitation and in the attitudes towards it, he assumes that the micro-level processes leading to the choice of cohabitation, or the attitudes towards it, are stable over time. Lapierre-Adamcyk, Le Bourdais and Marcil-Gratton (1999) analyze current attitudes towards marriage and cohabitation among young Ontarians and Quebecers, but do not examine the evolution of such attitudes over time. Bélanger and Turcotte (1999) do examine the changes over time in the effects of education and work on the 
Benoit Laplante, Caia Miller and Paskall Malherbe

choice of cohabitation or marriage as the form of the first union among Quebec women. They show that, contrary to what is assumed by the economic approach to human behaviour, these effects change over time. However, as their analysis is limited to Quebec, one cannot judge how the pace of these changes compares with that seen in Ontario or in other Canadian provinces. Had they made such comparisons, they might not have been able to explain any observed differences using the economic explanatory framework and the independent variables they chose. From a completely different perspective, and relying heavily on Parsons' and Bales's (1955) work on the family, Dagenais (2000) has examined changes in the contemporary family: although he presents his analysis as a general one, and as not specific to Quebec, Quebec is the only contemporary society he refers to; once again, this prevents any comparison with the rest of Canada or any other society.

Our view, developed in a related paper (Laplante, 2006), is that Quebec's shift in direction and recent rapid progress along the path of what has been called the second demographic transition have to be envisioned in the broader framework of a major transformation of the foundation of the normative system shared by the members of Quebec's main socio-religious group, French-speaking Catholics.

This paper is part of a research effort in which we look for empirical evidence to support this claim. According to our hypothesis, since the 1960s, Frenchspeaking Quebec Catholics have progressively shifted from a normative system based on Catholic morality, similar to or more conservative than that of our comparison group, English-speaking Ontario Protestants, to a normative system that is not founded on Christian morality. If this is true, it should be possible to see traces of that shift in the opinions of French-speaking Quebec Catholics on matters related to sexual and family behaviour from the 1950s to the beginning of the 2000s. More specifically, the opinions of French-speaking Quebec Catholics on these matters should have been similar to or more conservative than the opinions of our comparison group, English-speaking Ontario Protestants, at the beginning of this period, whereas they should be more liberal by the end of it.

In this article, we begin by describing the evolution of certain demographic behaviours in Quebec, as compared with Ontario. We present, in a condensed form, the rationale for our hypothesis. We then formulate specific empirical hypotheses, outline our data sources and methods, provide our results and present a discussion. 
The Evolution of Beliefs and Opinions as Matters related to Marriage and Sexual Behaviour among French-speaking Catholic Quebecers and English-speaking Protestant Ontarions

\section{Contemporary Behaviours in Quebec and Ontario}

From a general point of view, it is easy to argue that when it comes to demographic behaviours, Quebec is different from the rest of Canada, which, in contrast to Quebec, appears relatively homogeneous. However, the "rest of Canada" is not so homogeneous that one should not take into account a number of local peculiarities in order to effectively study the full range of differences that may be found there. When we focus on the case of Quebec, Ontario, because of the size of its population, its nearby location, the structure of its economy and its comparable history, offers a far better comparison than the whole of the rest of Canada.

Table 1 compares family structures in Quebec and Ontario using data from the 2001 census and provides information about the respective importance, in each of the two provinces, of families with and without children; it also provides information about the types of unions of couples with children at home. As one can see, childless families are slightly more common in Quebec than in Ontario, as are lone-parent families. However, the biggest difference between the two provinces involves common-law unions. We learn from the 2001 census that $30 \%$ of couples live in common-law unions in Quebec, whereas only $11 \%$ do so in Ontario. We also learn that $21 \%$ of Quebec families with children are headed by a couple living in a common-law union, as compared with only $6 \%$ of Ontario families in that category. To put it more clearly, in more than one out of four two-parent families in Quebec, the parents live in common-law unions, whereas this is the case in less than one out of ten two-parent families in Ontario.

Figures 1 to 4 give an overview of the evolution of certain demographic behaviours in Quebec and Ontario over several decades. Figure 1 shows the evolution of the crude marriage rate in Quebec and Ontario from 1950 to 2003. From 1950 to the mid-1960s, the crude marriage rate decreased in both provinces, and was always lower in Quebec than in Ontario. From the mid1960 s to the beginning of the 1970s, it increased and remained similar in both provinces. The pace of the increase slowed in Quebec at the beginning of the 1970s. The peak of the increase was reached in the mid-1970s in both provinces. The rate then started to steadily decline, with the decrease occurring much more quickly in Quebec than in Ontario. As we will see several times in this section, long series can only be obtained for simple demographic measures. Some related and more refined measures are available for recent years. We thus know that in 2002 , the total first marriage ratio among females under 50 years of age was 333.7 per 1,000 in Quebec and 558.7 per 1,000 in Ontario, which is $40 \%$ lower in Quebec than in Ontario. The same ratios for males were 303.4 in Quebec and 531.1 in Ontario, which is $43 \%$ lower in Quebec than in Ontario. 
Table 1

Census Families in Private Households by Family Structure and Presence of Children, by Provinces and Territories: 2001

\begin{tabular}{lcc}
\hline & Quebec & Ontario \\
\cline { 2 - 3 } All families & & \\
Without children at home & $37.22 \%$ & $34.79 \%$ \\
$\quad$ With children at home & $62.78 \%$ & $65.21 \%$ \\
Two-parent families & & \\
$\quad$ Families of married couples & $69.80 \%$ & $88.96 \%$ \\
Families of common-law couples & $30.20 \%$ & $11.04 \%$ \\
Families with children at home & & \\
Families of married couples & $52.87 \%$ & $70.64 \%$ \\
Families of common-law couples & $20.66 \%$ & $6.00 \%$ \\
Lone-parent families & $26.47 \%$ & $23.36 \%$ \\
& & \\
\hline
\end{tabular}

Source: Statistics Canada, Census of Population, authors' calculation

Figure 2 shows the evolution of the crude divorce rate in Quebec and Ontario from 1950 to 2003. We see that until 1970, divorce was uncommon in Quebec and the rate was thus lower than in Ontario. The rate increased in both provinces from 1970 to 1990, but at a faster pace in Quebec until the last portion of the 1970s. The rates have been similar in both provinces since the beginning of the 1990s and have tended to decrease. Again, we may use a more refined measure for recent years: in this case, the 30-year total divorce rate per 1,000 marriages. This measure is built in pretty much the same fashion as the total fertility rate, and can be interpreted as the proportion of existing marriages that would end in divorce in their first 30 years if the current divorce ratios per years of marriage duration were applied to them. In 2002, the 30-year total divorce rate per 1,000 marriages was 476 in Quebec and 349 in Ontario, which is $36 \%$ higher in Quebec than in Ontario. In other words, the crude marriage rate is not the best way to compare the two provinces because fewer people marry in Quebec than in Ontario, but a higher proportion of these married people divorce in Quebec than in Ontario. 
The Evolution of Beliefs and Opinions on Matters related to Marriage and Sexual Behaviour among French-speaking Catholic Quebecers and English-speaking Protestant Ontarians

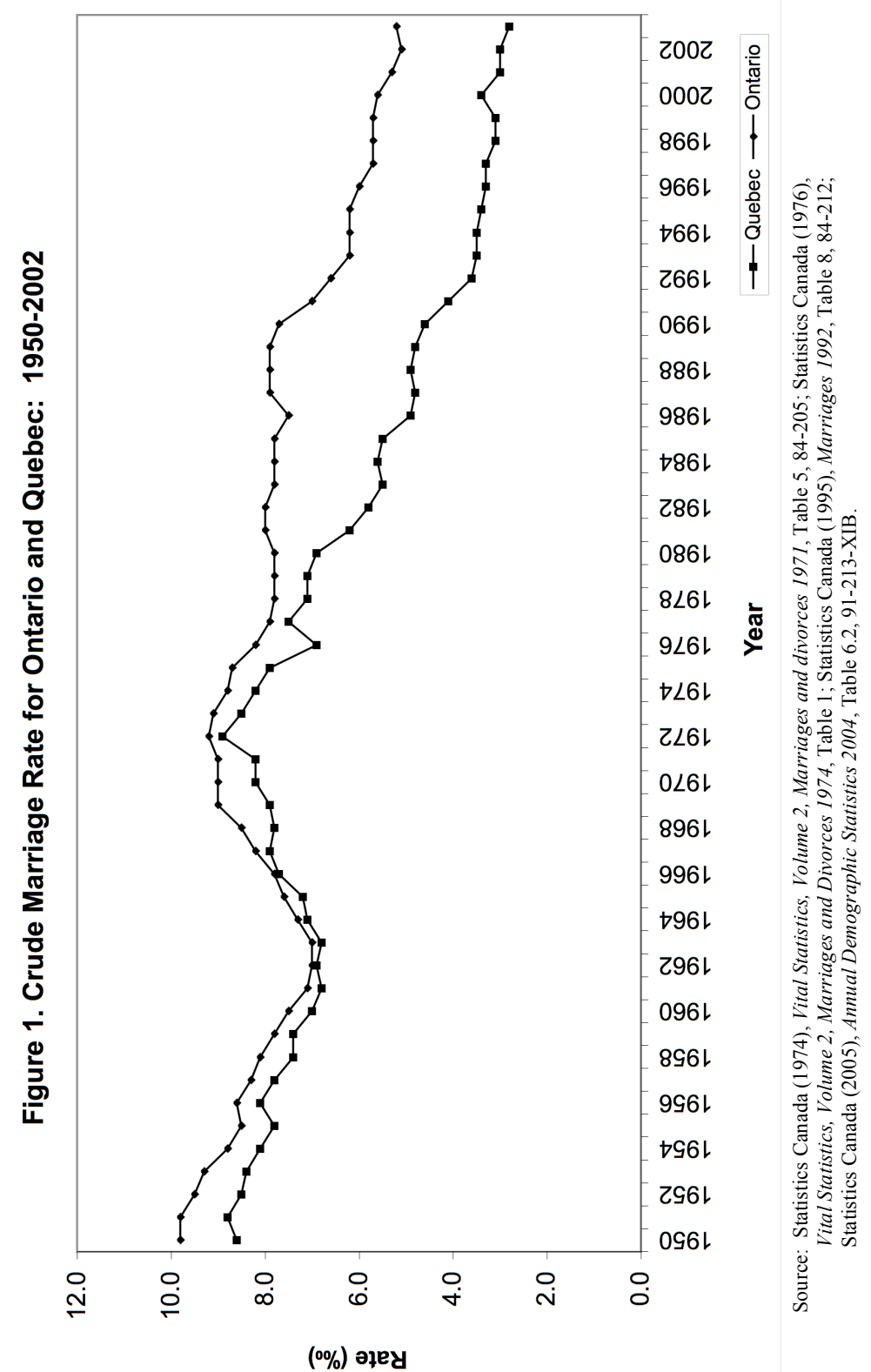


Benoit Laplante, Caia Miller and Paskall Malherbe

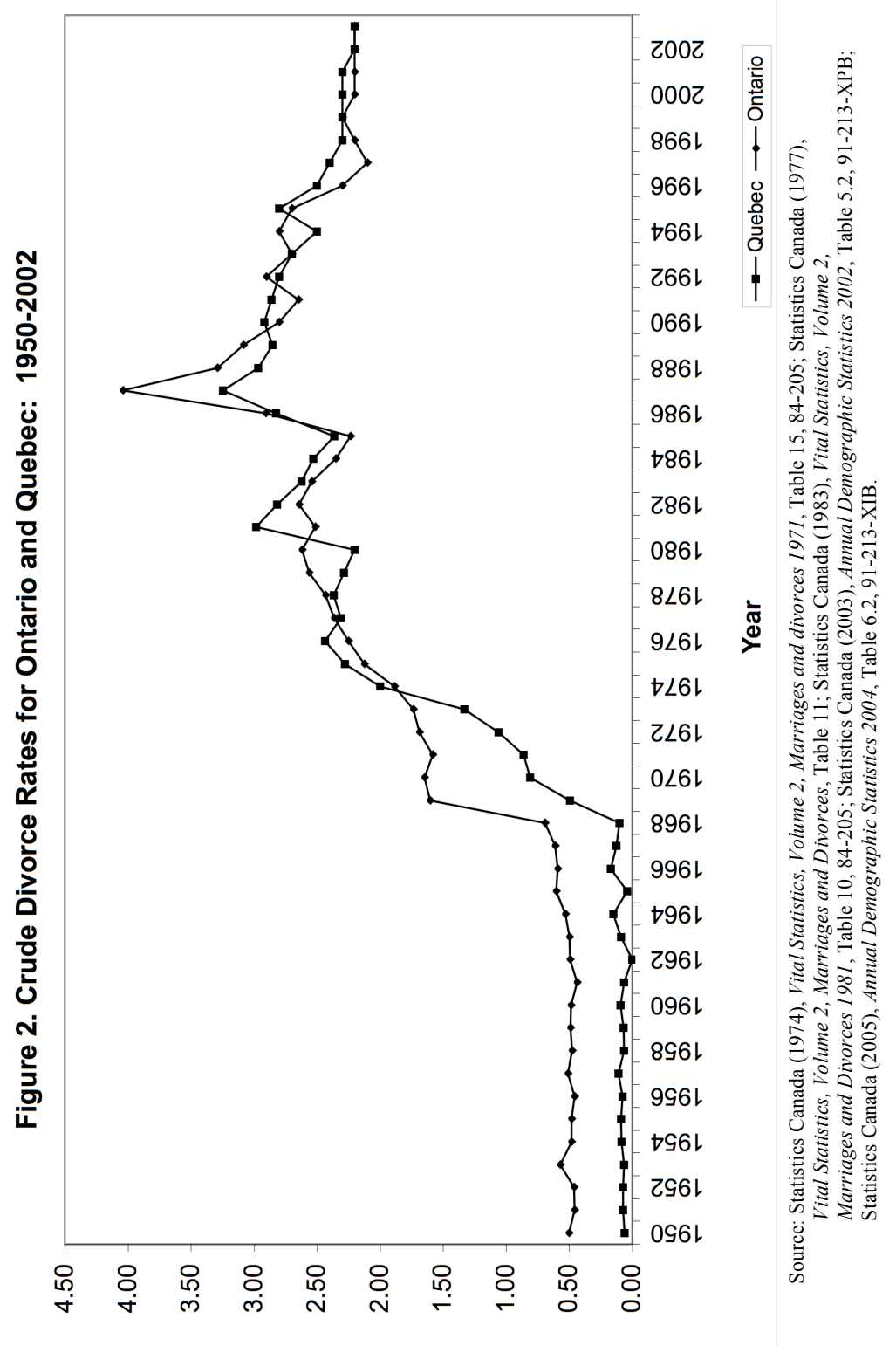

(\%\%) әңеу 
The Evolution of Beliefs and Opinions as Matters related to Marriage and Sexual Behaviour among French-speaking Catholic Quebecers and English-speaking Protestant Ontarions

Figure 3 reports the rate of induced abortions per 1,000 women aged 15 to 44 in Quebec and Ontario from 1970 to 2003. These rates remained lower in Quebec than in Ontario until the beginning of the 1990s, were similar from the beginning of the 1990s up to the final years of the century, and then remained high in Quebec while they decreased in Ontario. A somewhat different measure, the ratio of induced abortions per 100 live births, gives a sharper picture of the current difference: in 2002, the ratio of induced abortions per 100 live births was 42.6 in Quebec and 29.7 in Ontario, which is 43\% higher in Quebec than in Ontario.

Figure 4 shows the evolution of the total fertility rate in Quebec and Ontario from 1950 to 2003 . From 1950 to the beginning of the 1960 s, the rate remained stable in Quebec and was higher than in Ontario, where it increased. In both provinces, the rate decreased quite steadily from the beginning of the 1960s to the beginning of the 1980s. During this period, it was lower in Quebec than in Ontario. From the beginning of the 1980 s to 2003, the rate remained quite stable in Ontario, while it first decreased and then increased in Quebec. Since the mid1990 s, the rate has been similar in both provinces. In 2002, the total fertility rate was 1,460.5 in Quebec and 1,474.1 in Ontario, which is just under 1\% lower in Quebec than in Ontario.

In a nutshell, although people in Quebec marry less, and divorce more if they marry, and although Quebec women abort more than Ontario women, women in both provinces give birth to roughly the same number of children.

The overall picture of the current situation regarding family-related behaviours in Quebec can thus be summarized as follows. In this province-where $83 \%$ of the people report that they are Catholic $-30 \%$ of couples are not married, almost half of the marriages end in divorce, $28 \%$ of couples with children at home are not married, and, very roughly, three out of ten pregnancies are ended by induced abortion. All of these figures are higher than in the neighbouring province of Ontario, where only $35 \%$ of the people are Catholic and $16 \%$ say that they have no religion. So the big question is: How is it that the only Canadian province where the vast majority of the people say they are Catholic is also the province where people manage their sexual, reproductive and family lives in ways that are the least compatible with Catholic morality?

Various hypotheses have been proposed to explain why people choose commonlaw union over marriage. Some of them, such as the selection hypothesis, hypotheses based on the cost of children and the expected cost of separation, and hypotheses in which common-law union is seen as a "budget form" of marriage, could be discussed while looking for an explanation of this difference between two provinces that also differ in some aspects of their economies and legal 


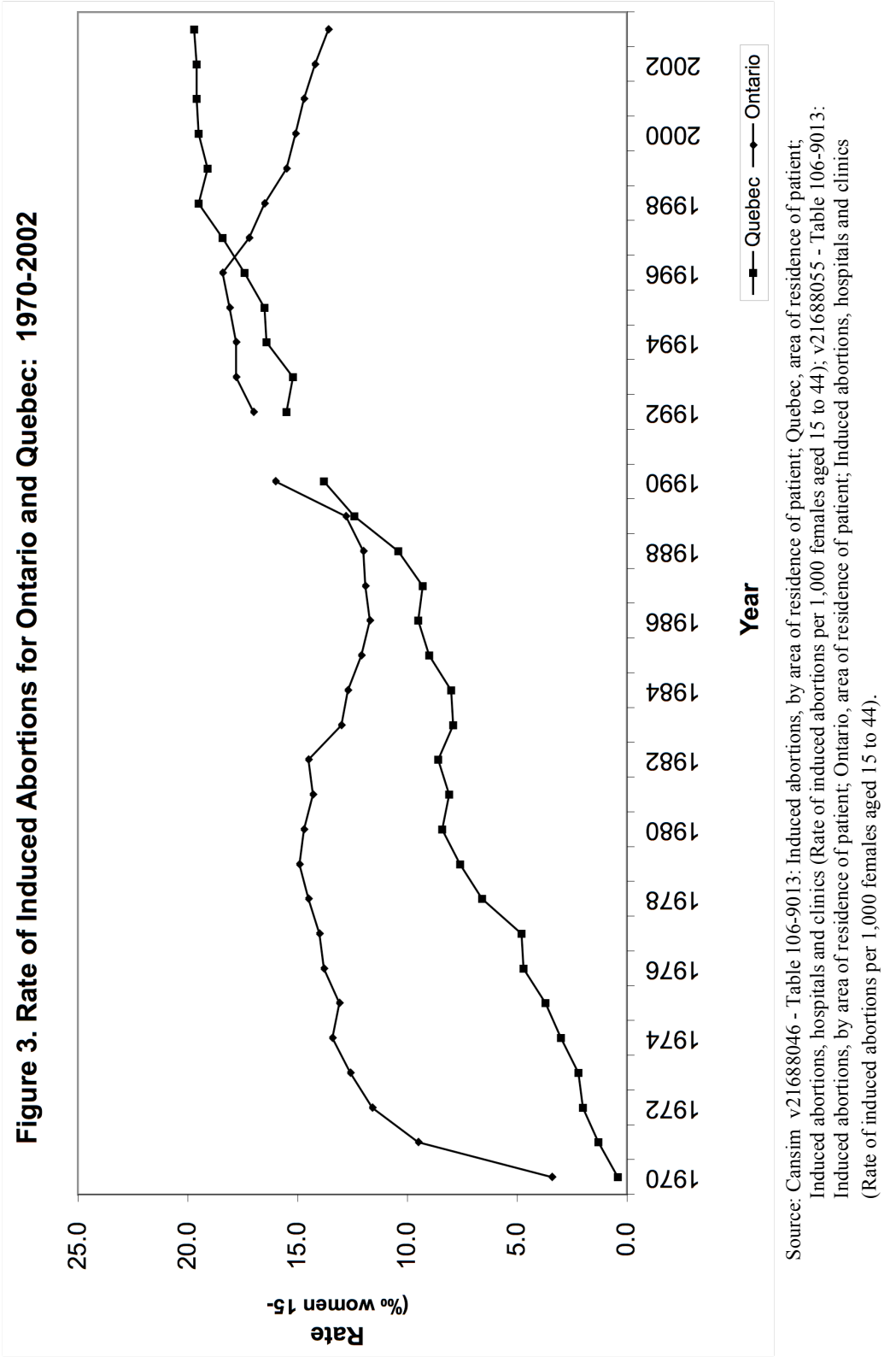


The Evolution of Beliefs and Opinions on Matters related to Marriage and Sexual Behaviour among French-speaking Catholic Quebecers and English-speaking Protestant Ontarians

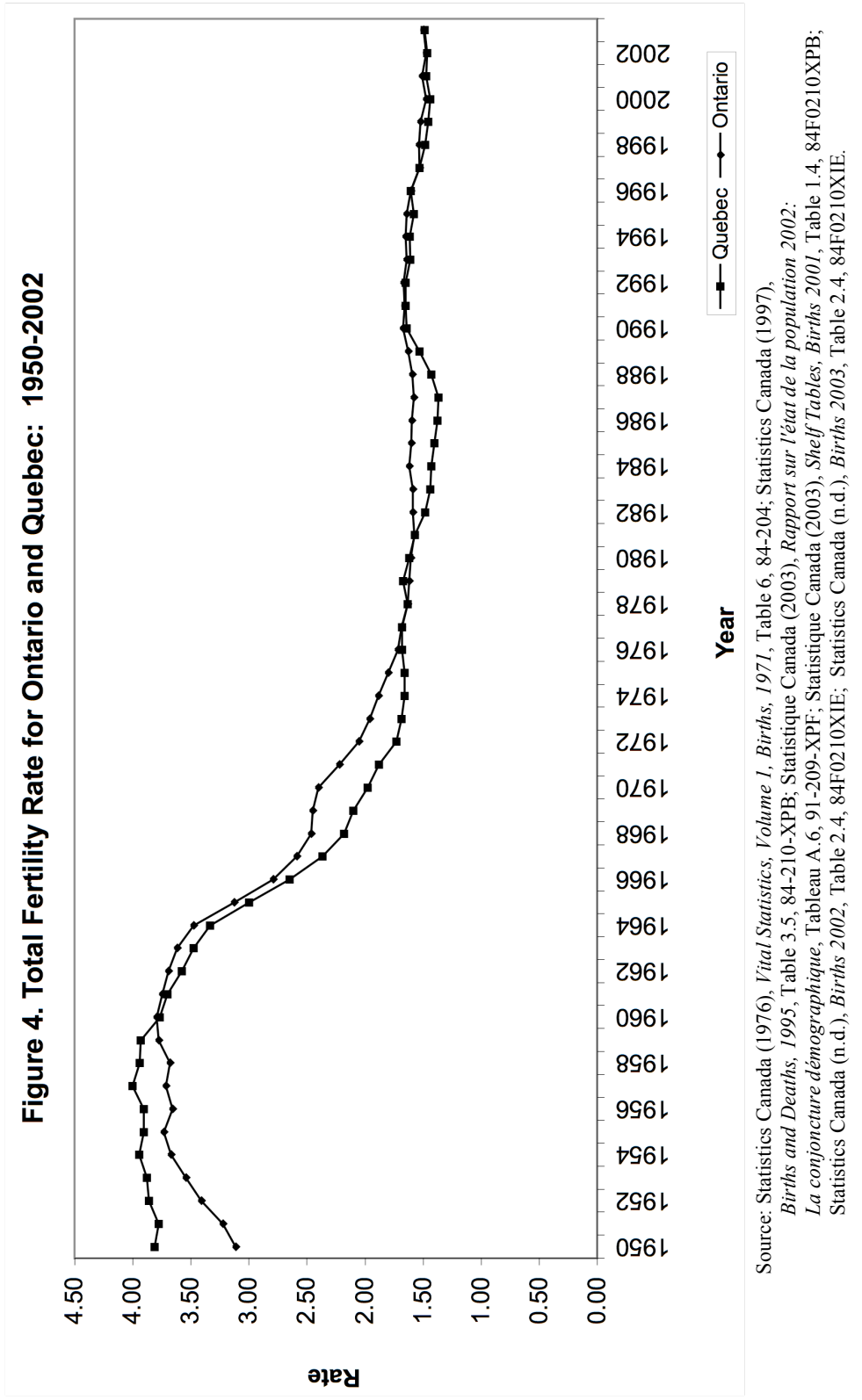


Benoit Laplante, Caia Miller and Paskall Malherbe

systems, although a recent study of demographic and socioeconomic differences between cohabiting and married couples in Quebec and Canada (Kerr, Moyser and Beaujot, 2006) shows quite convincingly that the choice between the two forms of union is not related in the same way to socioeconomic characteristics in Quebec as it is in the rest of Canada.

However, there are relatively few hypotheses about the decision to divorce, the most common being that people who had bad experiences in childhood or experienced the divorce of their parents are more prone to divorce. But it is hard to see how such psychosocial explanations could be used to explain differences in divorce rates in the two provinces. Finally, we do not know of any proposed explanation of the use of abortion as a method of contraception that does not explicitly involve moral norms. In other words, it seems difficult to imagine an explanation of the pattern of these differences in behaviour between the two provinces that does not directly look into what sustains the norms, values and beliefs that guide people in their behaviour in family-related and sexual matters, and into the process through which these norms, values and beliefs change when behaviours change so drastically over time, and in such a different way in two societies that are part of the same country and have relatively similar standards of living.

\section{An Explanation based on Religion as a Shaper of Social Groups}

The fact that Quebec ceased to be a Catholic society during what is known as the Quiet Revolution and that Catholic French Canadians from Quebec started to move away, in their daily lives and especially in their sexual and family lives, from the morality of the Catholic Church during this period has already been noted by several demographers (e.g. Beaujot, 2000). However, the underlying mechanisms and significance of this co-occurrence are not yet fully understood. Our view is that the differences in demographic behaviour between Quebec and Ontario - or between Quebec and the rest of Canada - that developed over the last four decades should be envisioned in the broader framework of a major transformation of the foundation of the normative system shared by the members of Quebec's main socio-religious group, French-speaking Catholics.

As we argue elsewhere (Laplante, 2006), these differences can be explained, at least in part, by the fact that almost all of Quebec's French-speaking population during the 1960s belonged to the Roman Catholic Church, at a time when the local Catholic Church was changing in one important way while failing to change in another equally important one. More specifically, we argue that the Church authorities' refusal either to change their doctrine on marriage and 
The Evolution of Beliefs and Opinions as Matters related to Marriage and Sexual Behaviour among French-speaking Catholic Quebecers and English-speaking Protestant Ontarions

sexuality or to allow the laity to play a decisional role in the definition of doctrine and the orientation of pastoral activities gave Quebec Roman Catholics a strong motive for abandoning the Christian tradition as the provider of moral guidelines on sexual and family matters; at the same time, the withdrawal of local Roman Catholic authorities from the set of institutions that structured people's lives "from the cradle to the grave" made it possible for Quebecers to actually abandon this tradition.

As explained by Baum (1990), the Roman Catholic Church's main tendency since the 19th century had been to resist the widespread movement towards democratization of its political structures and to affirm the Church as a monarchy; the adoption of the dogma of papal infallibility, in 1870, was the acme of this trend. The Church's authority had always been centralized but, since 1870 , the definition of the magisterium on moral theology has practically rested in the sole person of the head of the Church (Mahoney, 1987). Theological and moral doctrine has become highly intellectualized, and theology, as a discipline, is held to be a science in the strictest sense (Ratzinger, 1987). Important matters of faith and morality, and not only the organization of the Church, are expressed as rules of law-the Canon Law, which binds all Roman Catholics.

Although all Western Christian churches have inherited the same basic theology and moral doctrine, the Protestant and Catholic Churches differ on two important matters in regard to the topic discussed here.

The first difference is that, although mainstream Protestant churches kept most of the prevailing traditional Christian moral doctrine at least until the beginning of the 20th century, from the start they all differed from Catholicism on one topic: divorce. Divorce is permitted by all Protestant churches and, in most of them, remarriage is also allowed and even encouraged (Phillips, 1988). In the wake of the Reformation, the State seized the Church's jurisdiction over marriage and related topics in both the civil and religious spheres (Kitchin, 2002 [1912]). Thus, in countries where the Reformation prevailed, ecclesiastical courts disappeared, and a divorce granted by a State court, parliament or the sovereign himself (or herself) dissolved the marriage both as a contract and as a religious bond. As long as divorce was an exceptional occurrence, these differences remained of little consequence. In Canada, the context changed somewhat when the number of couples requesting separation or divorce increased among Protestants as well as Catholics, and when the Canadian Parliament made divorce easier. From then on, what had been of little consequence became a huge difference: Protestants were able to get a divorce that put an end to their marriage as both a civil and a religious bond, whereas 
Benoit Laplante, Caia Miller and Paskall Malherbe

Catholics were able to get a divorce that had civil effects but nevertheless kept them married and unable to remarry in their own religion.

The second difference is that Protestant churches have moved away from Catholicism's centralist trend and have reinstated the autonomy of national churches, which never disappeared in Eastern Orthodoxy. Even in the Anglican Church, the closest to Catholicism, national synods may or may not enforce the canons of the Church of England. Furthermore, in the Protestant world, theology and moral theology are areas of debate, and whatever is accepted as right by the relevant collegial authority becomes right. Decentralization and a belief that matters of faith and morality are to be defined by the assembly of believers in its historical circumstances have given Protestant churches the latitude to deal with matters of morality in a wide variety of ways. The important point is that this latitude existed and was used, and is still used, to accommodate a wide range of conceptions of moral behaviour that make it possible to keep divorce, remarriage of the divorced, contraception, women ministers, and even, in some cases, homosexuality and abortion within the realm of religious morality.

No such latitude existed within the Roman Catholic Church in the 1960s. Although we have no direct evidence from interviews or published material, it is not unreasonable to imagine that Quebec Roman Catholics might have been satisfied if their Church had followed, at least with respect to contraception, a path and a timing similar to the course taken by the Anglican Church between 1920 and 1958 (Noonan, 1965). The Roman Catholic Church did not.

Protestants, who all had the power to define religious morality within some form of deliberative body, were able to keep adapting this morality to the new realities. From the Protestant perspective, religious morality is open to change and does change. This has two consequences. First, this makes it possible both to remain within the Church or retain religious beliefs and to live according to an updated religious ethic, either because one's particular church or congregation has updated its moral doctrine, or is likely to do so, or because an equivalent Protestant church or congregation has or will have done so. Second, by keeping religion relevant to such issues, this continues to legitimate the control of sexual and reproductive behaviour by churches and, more importantly, by the community. Within the Protestant world, the act of matrimony is relevant as an orderly moral event although, in the Protestant doctrine, as in the Eastern Orthodox doctrine, marriage is not a sacrament in the sense that it is in the Roman Catholic Church.

More importantly, this deepening of the normative gap between the Catholic and the Protestant worlds happened at a time when almost all of the institutions structuring the everyday lives of French-speaking Roman Catholic Quebecers 
The Evolution of Beliefs and Opinions as Matters related to Marriage and Sexual Behaviour among French-speaking Catholic Quebecers and English-speaking Protestant Ontarions

"from the cradle to the grave" were changing. As shown in recent scholarship focusing on the intellectual history of the Quebec Church before and during the Quiet Revolution (Warren and Meunier, 1999; Meunier and Warren, 2002; Gauvreau, 2005), these institutions either had been handed over to the Quebec government by the religious communities that had owned and managed them for centuries, as in the case of health and education, or had simply abandoned their affiliation with the Roman Catholic Church, as in the case of labour unions and credit unions, with all of this occurring as part of the internal dynamics of the Church rather than as the result of a Quebec government initiative. In less than ten years, the Roman Catholic Church's authority and influence over all of these institutions ended completely, and the institutions became officially nonconfessional. As a result, for the first time in Quebec's history since the Conquest, not being in conformity with the Roman Catholic Church ceased to have practical consequences for one's entitlement to health, education and a host of other services related to everyday life or important occasions.

In other words, the Catholic Church in Quebec gave up its power over these institutions, and its most obvious and effective means of controlling its members, at the same time as the Holy See was tightening its control over the definition of right and wrong and using it to ensure that the doctrine would not change. This combination created a situation inviting Quebecers to act as though the Church and its doctrine were no longer relevant. Given the circumstances, Quebecers chose to accept the invitation, and began treating the Church, and religion as well, as irrelevant in matters of family and sexual life.

\section{Hypotheses}

According to our general hypothesis, since the 1960s, French-speaking Quebec Catholics have progressively shifted from a normative system based on Catholic morality, similar to or more conservative than that of our comparison group, English-speaking Ontario Protestants, to a normative system that is not founded on Christian morality. If this is true, it should be possible to see traces of that shift in the opinions of French-speaking Quebec Catholics on matters related to sexual and family behaviour from the 1950s to the beginning of the 2000s. More specifically, the opinions of French-speaking Quebec Catholics on these matters should have been similar to or more conservative than the opinions of Englishspeaking Ontario Protestants at the beginning of this period, whereas they should be more liberal by the end of it.

The main problem in such an endeavour is, of course, the availability of data. As detailed in the next section, we use data from Gallup polls conducted from 1957 onwards, which enables us to follow the opinions of the two groups we are 
Benoit Laplante, Caia Miller and Paskall Malherbe

interested in over more than 40 years. The main limitation with these data is the availability of long series of questions on the same topic. Gallup questionnaires typically include questions on topics that are known to be of public interest or political relevance at the time of the survey. Although some questionnaires included questions about free love and related matters, we were unable to find questions from which it would have been reasonable to build a series on the acceptance of common-law union. We were able to find questions on the acceptance of contraception from the mid-1960s to the mid-1970s, which is, however, a rather short span for our purposes. There are only three topics related to our interests for which it proved possible to build long series of questions: religious attendance, acceptance of abortion, and acceptance of homosexuality. The series on religious attendance ranges from 1957 to 1999, while the series on the acceptance of abortion and homosexuality range from the mid-1960s to 2000 .

Religious attendance is not an opinion but in fact a behaviour. Given that this behaviour is an indicator of the importance that people give to religion in their lives, that such a topic is clearly related to our area of interest, and that we do not know of any other data source that provides such a long series of data on this topic and for the two groups we are interested in, we chose to use this survey topic.

Homosexuality is not a demographic behaviour; but a high level of acceptance of homosexuality within a group is clearly an indicator that this group has moved away from the Catholic doctrine that strongly rejects homosexuality as part of its doctrine of natural law seen as the foundation of moral law in sexual matters.

The level of acceptance of abortion is the only series that is perfectly suited to our hypothesis, as it is related as directly as possible to the use of abortion as a contraceptive method, and as acceptance of abortion is strongly rejected by Catholic morality.

\section{Data and Methods}

We compare the evolution of the opinions of French-speaking Catholic Quebecers and English-speaking Protestant Ontarians on matters related to marriage and sexual behaviour using data from Gallup polls conducted from 1957 onwards and available to university researchers through the Carleton University Library Data Centre (see Bibby, 1987, 2002, and Gallup and Lindsay, 1999, for examples of similar uses). 
The Evolution of Beliefs and Opinions as Matters related to Marriage and Sexual Behaviour among French-speaking Catholic Quebecers and English-speaking Protestant Ontarions

We use the data for Ontario and Quebec from 86 different pools; each pool provides around 600 cases. The question on religion virtually did not change over time. Until January 1959, the question on religion was "Do you mind telling me if you are Roman Catholic, Protestant or Jewish?," with "Other" as a possible answer. The question changed slightly in January 1959 and became "Now for a question on religion. What is your religious preference-Protestant, Roman Catholic, or Jewish?," with "No religious preference" as a new possible answer.

The data from the pools are poststratified and weighted according to contemporary censuses. We use questions on the respondents' opinions on religious attendance, contraception, homosexuality and abortion. Answers to these questions are recoded so as to contrast all levels of traditional opinions with all levels of liberal opinions, while separating out alternative answers such as "qualified," "no opinion" and "refused to answer". Analyses are conducted using multinomial logit models, and using the liberal answer as the reference category of the dependent variable.

Models have been estimated twice, first using province of residence, religion and language as distinct variables and then combining them to form a single multiple categories variable. These operations allowed us to test whether the effects of these variables were simply additive or, on the contrary, reflected the existence of distinct social groups defined by the combination of province of residence, religion and language. In all cases, Ontario, Protestant and English were used as the reference categories of the independent variables. All models included other presumably relevant variables, such as sex, age and education, the effects of which were thus controlled for. Tests were adjusted to take into account unequal sampling and, as much as possible, design effect. In the cases where tests show that answers are distributed as if there were distinct social groups defined by language, religion and province of residence, the estimates associated with the French-speaking Catholic Quebecers category are estimates of the odds of French-speaking Catholic Quebecers providing answers of any type but the liberal answer, relative to the odds of English-speaking Protestant Ontarians providing a liberal answer.

\section{Results}

The tests show that aggregating province of residence, religion and language consistently provides a statistically significant, better explanation of the distribution of answers than assuming that the effects of these variables are simply additive. Thus, on matters related to marriage and sexual behaviour, 
Benoit Laplante, Caia Miller and Paskall Malherbe

Canadian society does in fact appear to be structured in groups defined by the combination of political territory, language and religion.

Estimates of the numerous regression-like models are reported in graphs (see Figures 5 to 8) that show the evolution over time in the odds of French-speaking Catholic Quebecers providing a conservative or some alternative answer rather than a liberal one relative to the odds of English-speaking Protestant Ontarians providing corresponding answers. The questions we are interested in are spread over time in an almost erratic manner. The intervals of the "time" scale are thus unequal; our attempts to impose equal intervals on the figures were not very helpful.

Religious attendance (Figure 5). Religious attendance is commonly known to have dropped sharply among French-speaking Quebec Catholics after 1967, but our data show that their level of attendance remained higher than that of English-speaking Ontario Protestants until 1991. The level was apparently lower among French-speaking Quebec Catholics than English-speaking Ontario Protestants in 1997, but both groups showed similar levels of attendance in 1999.

Contraception (Figure 6). The series stops in 1975. Throughout the period, French-speaking Quebec Catholics consistently had a higher probability of providing a more conservative opinion. However, from 1967 onwards, they also had a higher probability of either giving a qualified answer or refusing to answer. Such a pattern of opinions can be interpreted as reflecting a period of division of opinion, as some people maintain the traditional view while others either provide some kind of "middle of the road" opinion or simply refuse to admit that they do not agree with the opinion that still prevails in their group.

Homosexuality (Figure 7). Questions were asked on homosexuality in 1968, when the federal Parliament removed this behaviour from the Criminal Code, and were asked once again in 1977, and then regularly through the 1990s and in 2000 , presumably because questions related to homosexual rights, such as social benefits for same-sex partners, adoption by same-sex couples, and homosexual marriage, were being publicly debated. The overall trend indicates that Frenchspeaking Quebec Catholics seemed to have been more tolerant towards homosexuality from the onset of the series, which, unfortunately, starts after the time at which, according to our hypothesis, their opinion should have started to shift. From 1994 to 2000, French-speaking Quebec Catholics clearly held a more liberal opinion on homosexuality than English-speaking Ontario Protestants. 
The Evolution of Beliefs and Opinions on Matters related to Marriage and Sexual Behaviour among French-speaking Catholic Quebecers and English-speaking Protestant Ontarians

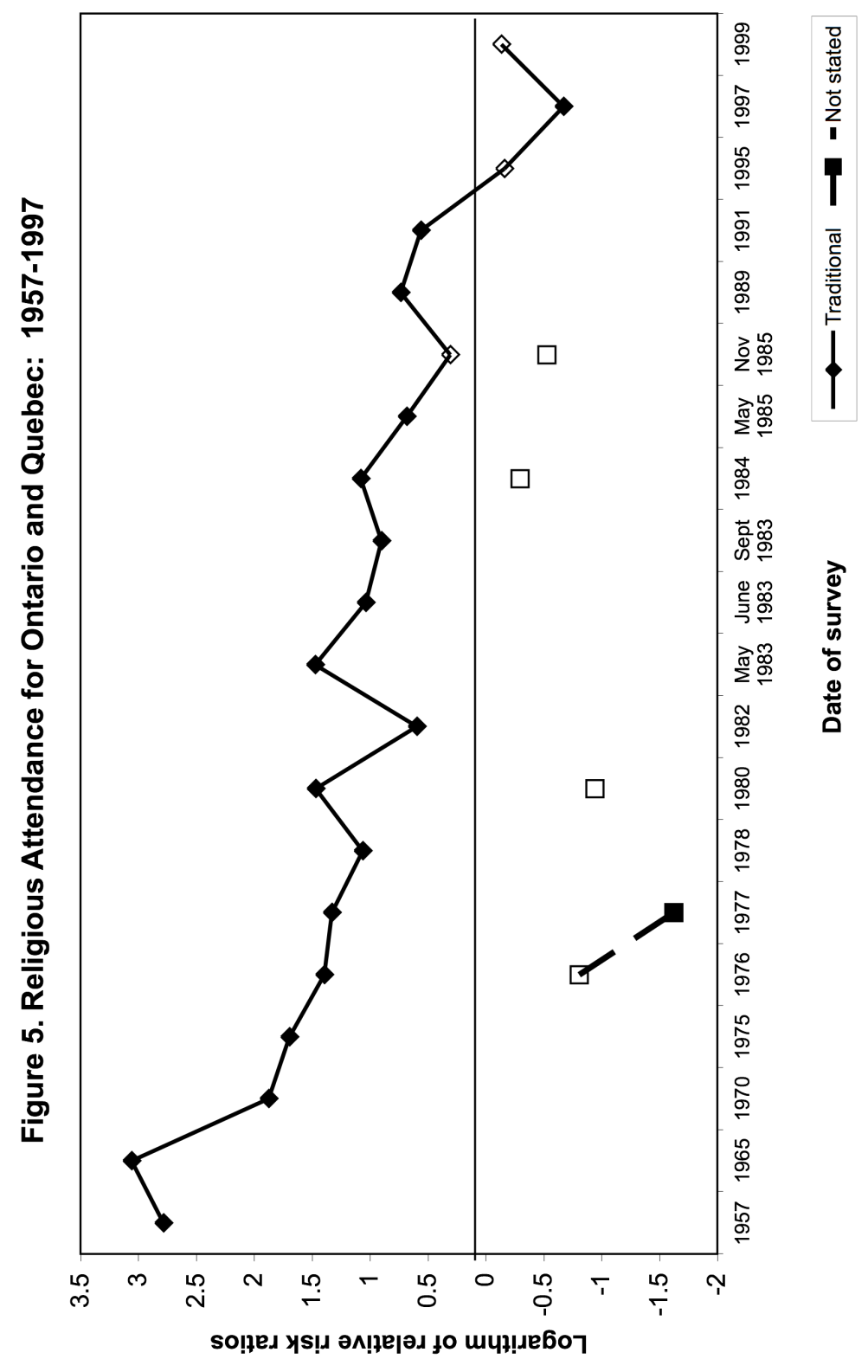




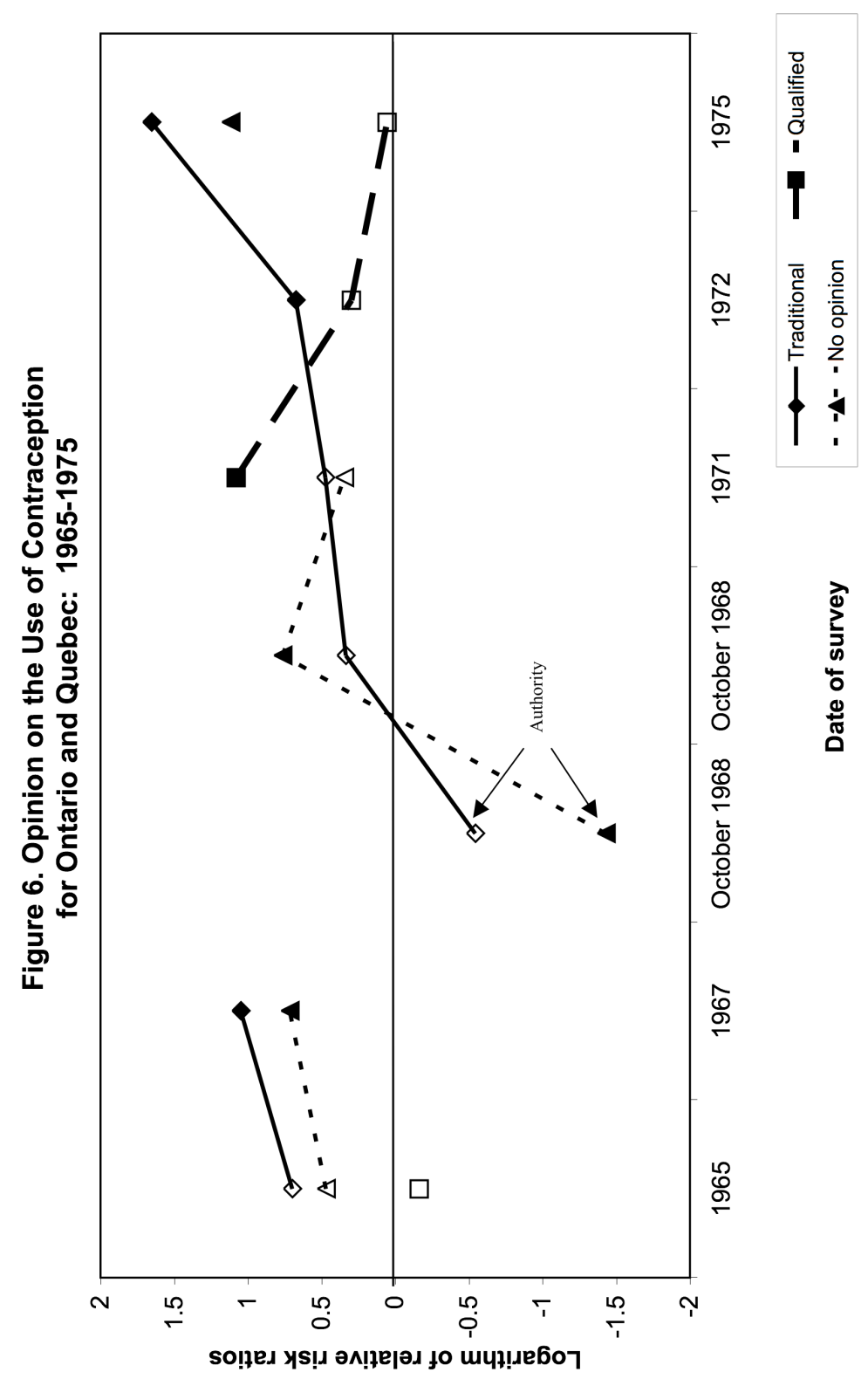


The Evolution of Beliefs and Opinions on Matters related to Marriage and Sexual Behaviour among French-speaking Catholic Quebecers and English-speaking Protestant Ontarians

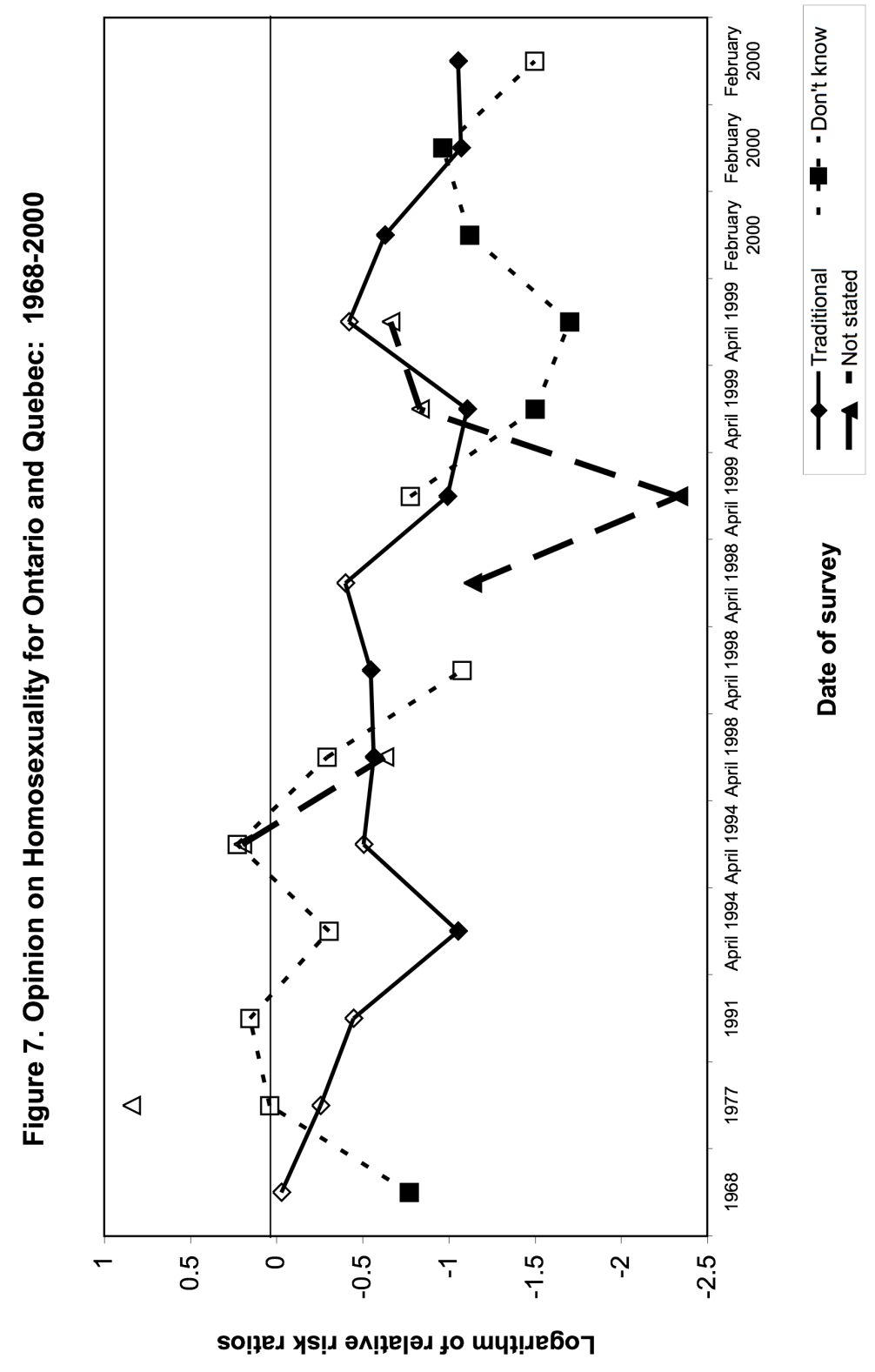


Benoit Laplante, Caia Miller and Paskall Malherbe

Abortion (Figure 8). The overall trend is the one we expected, although the pattern also seems to reflect differences in the rhythm at which the opinions shifted in both groups. Until the mid-1970s, French-speaking Quebec Catholics clearly held a more traditional opinion than English-speaking Ontario Protestants. In 1975 and 1983, French-speaking Quebec Catholics were more likely than English-speaking Ontario Protestants to provide a more traditional answer or a qualified one. This likely indicates that the opinion of Frenchspeaking Quebec Catholics was moving towards a level of acceptance of abortion similar to that of English-speaking Ontario Protestants. Frenchspeaking Quebec Catholics were still more likely to provide a qualified opinion in 1989. By 1991, they were less likely to provide a qualified opinion and, by 1995, they were less likely to provide a conservative opinion. This new difference between the two groups becomes blurred in the following years. The most likely explanation is that, after 1995, English-speaking Ontario Protestants had reached the level of acceptance of abortion that French-speaking Quebec Catholics had reached a few years before.

\section{Discussion}

Our general hypothesis is that Quebec's relatively rapid progress along the path of what seems to be the second demographic transition is a consequence of a major transformation of the foundation of the normative system shared by the members of Quebec's main socio-religious group, French-speaking Catholics. Using data from Gallup polls, we searched for traces of that shift in the opinions of French-speaking Quebec Catholics on matters related to sexual and family behaviour from the 1950s to the beginning of the 2000s. We expected the opinions of French-speaking Quebec Catholics on these matters to have been similar to or more conservative than the opinions of our comparison group, English-speaking Ontario Protestants, at the beginning of this period, and to have been more liberal by the end of it. Given the limitations of the data, we were restricted to four topics: religious attendance, opinion on the use of contraception, tolerance towards homosexuality, and opinion on abortion.

The general result is that the changes that can be seen in these data are compatible with our general hypothesis. Over a 40-year period, the religious attendance of French-speaking Quebec Catholics decreased and became, for a time, lower than the level of religious attendance of English-speaking Ontario Protestants; in recent years, the levels of religious attendance of the two groups are found to be similar. The opinion of French-speaking Quebec Catholics on contraception seems to have been starting to shift from clearly conservative 
The Evolution of Beliefs and Opinions on Matters related to Marriage and Sexual Behaviour among French-speaking Catholic Quebecers and English-speaking Protestant Ontarians

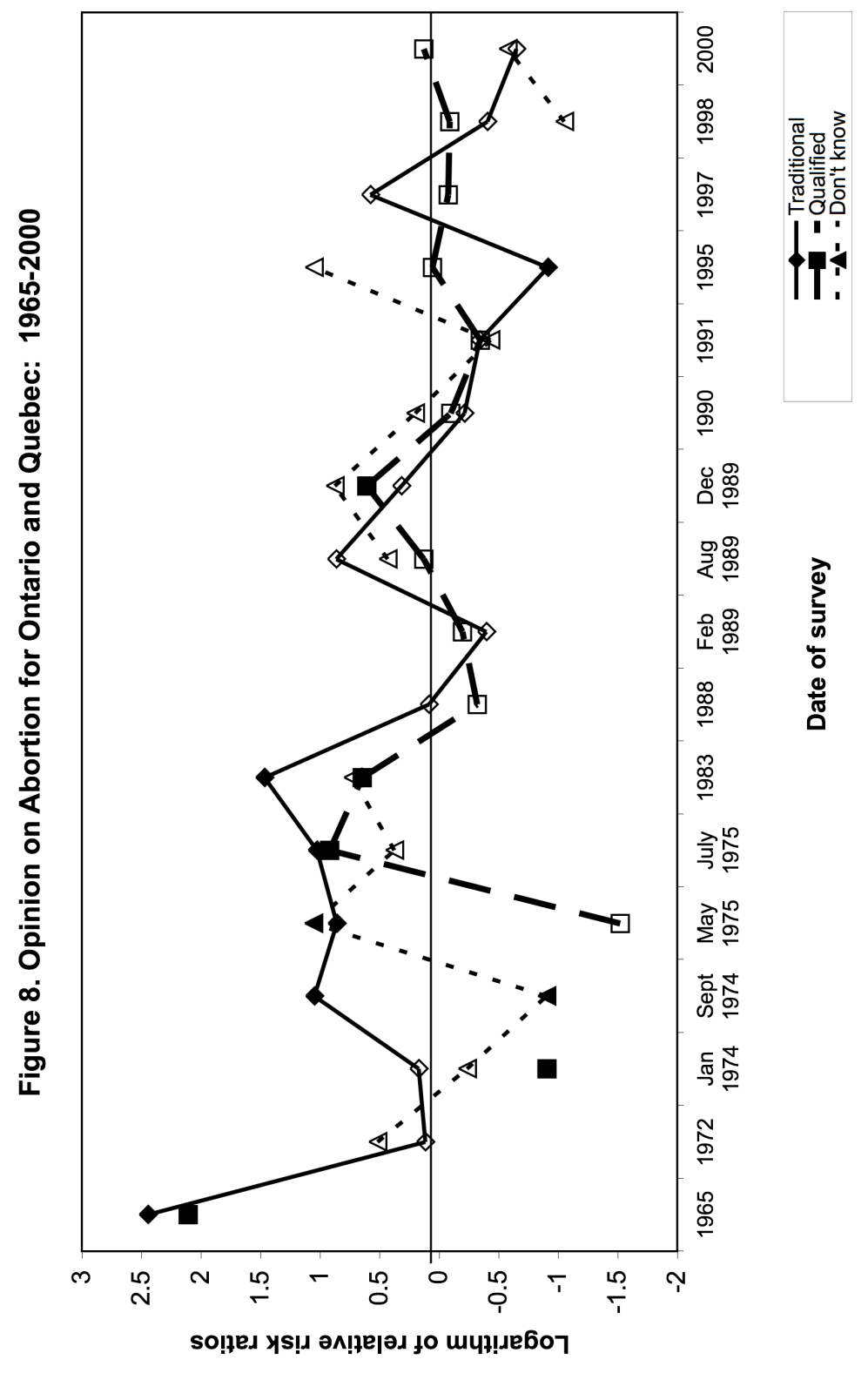


Benoit Laplante, Caia Miller and Paskall Malherbe

towards a more liberal opinion during the 1970s. By the 1990s, Frenchspeaking Quebec Catholics were more tolerant towards homosexuality than English-speaking Ontario Protestants. While French-speaking Quebec Catholics clearly held more conservative opinions on abortion in the 1960s, by 1995 they had a more liberal opinion than English-speaking Ontario Protestants.

The main limitation of this analysis is obviously the availability of data. Although we had access to Gallup polls from 1953 to 2000, we were not able to build more than four series of questions related to the topics we were studying. Only two of these series, religious attendance and opinion on abortion, cover the largest portion of the period we are interested in. Only one, opinion on abortion, is exactly the kind of series we were looking for. Further research would definitely be helpful, if the data existed to conduct this research.

This being said, these results on the evolution of the opinions of the two groups as well as the current differences between Quebec and Ontario and the evolution of the behaviours we report in the introduction all provide material to further develop our initial hypothesis.

In a few words, we find traces of a process in which the opinions of one group, English-speaking Protestant Ontarians, slowly change from traditional to nontraditional, whereas the opinions of another group, French-speaking Catholic Quebecers, rapidly change from very traditional to very non-traditional. We link these changes in opinions to the different processes through which each of the two groups managed the relation between their religion and the new realities that emerged over the period we are examining. English-speaking Protestant Ontarians, who were largely mainline Protestants during this period, were able to use the power or influence the faithful had within their churches to adapt their religious morality to the new realities. This process is a continuous one, which, as religious morality evolves, allows the believer to keep the Christian tradition as the intellectual foundation of the norms he or she lives by. French-speaking Catholic Quebecers were facing the same new realities as English-speaking Protestant Ontarians; but the combination, within the Roman Catholic Church, of centralized ecclesiastical and moral authority and the heavy reliance on religious rationalism in matters of morality hampered the faithful's adaptation of religious morality to the new realities, and thus created a situation in which the individual had to choose between religious belief and norms of behaviour adapted to the new realities. Unlike English-speaking Ontario Protestants, French-speaking Quebec Catholics could not have both. Circumstances made it possible for French-speaking Quebec Catholics to choose the contemporary norms over their traditional religious beliefs. One practical consequence of their choice was that almost immediately, the intellectual foundations of morality and norms, as well as the intellectual legitimacy of a number of legal institutions 
The Evolution of Beliefs and Opinions as Matters related to Marriage and Sexual Behaviour among French-speaking Catholic Quebecers and English-speaking Protestant Ontarions

(e.g. marriage, the criminalization of homosexuality and abortion, etc.), disappeared.

To fully appreciate the significance of such a choice, it may be useful to contrast it with some related changes that occurred during the Reformation and during the French Revolution. The Reformation was conducted with the Lutheran idea that the Christian nations would be better at defending Christianity than the Roman Court. Basically, the Reformation transferred religious power to the State, while keeping most of the Christian tradition and most of the Canon Law as it existed at the time of the transfer. It is true that religious orders were dismantled, priests were allowed to marry, and divorce was authorized in limited circumstances. However, contraception, homosexuality and abortion remained sins and crimes, as did marital life outside of wedlock, and children born out of wedlock remained religiously and legally illegitimate. With the Reformation, Church and State became united as they never had been since the dawn of Christianity. In this respect, the French Revolution did the exact opposite: it threw Christianity out of the State. But it did this while keeping most of the Christian tradition and most of the implementation of this tradition in civil and criminal law. It is true that divorce was authorized - to be repealed during the Restauration - as was adoption, which was then almost as abhorred by the Catholic Church as divorce. However, contraception, homosexuality and abortion remained crimes, marital life outside of wedlock was still a disorderly conduct from the viewpoint of civil law, and children born out of wedlock were still legally illegitimate. To make it possible to keep all of these norms and institutions inherited from the Christian tradition within the context of a legal system that was explicitly not founded on Christian morality, the French Revolution provided its own version, a laicized version, of the "natural law" that Catholic scholars had developed over the centuries in their attempts to reconcile faith with reason. Except for divorce and adoption, all that was forbidden or prescribed on religious grounds remained forbidden or prescribed, but on purely rationalized grounds. Through laicization, the Christian God, as the source of moral law, was replaced by something much akin to the Stoic logos.

When English-speaking Ontario Protestants were confronted with the new realities of the second half of the $20^{\text {th }}$ century, they did as most mainline Protestants did in the rest of the world: they used the power they had within their churches to move their religious morality in the direction the world was taking. French-speaking Quebec Catholics could not do such a thing: they had to choose between the immutable Catholic morality and the new realities. Once they had chosen the new realities, they could not rely on the intellectual device the French Revolution had invented as a substitute for Christian belief, because the device had never been imported in Canada. 
Benoît Laplante, Caia Miller and Paskall Malherbe

Laicization is not secularization. Unlike secularization or industrialization, laicization is not a large-scale and encompassing social process, but rather an intellectual construction and a political project embodied in law. As an intellectual construction, it legitimizes the involvement of the State as a nonreligious institution and the expulsion of the Church - and of religion - from the institutions that organize people's lives and provide services that, in Western history, were long the province of the Church (e.g. registration of births; legitimization, registration and dissolution of marriages; management of schools and hospitals). It legitimizes the fact that, through laicization and the legal structure that implements it, the institutions that are associated with birth and matrimony become purely civil concerns and purely the concerns of the State. In the many countries where the civil law implements the principles of laicization, registration of births is mandatory and is typically a parental responsibility; religious marriage has no civil effect and the law requires that the civil marriage be performed before the religious ceremony; and birth and marriage certificates are issued by the State. These prescriptions relative to identity and marriage are the most important practical implementations and the most obvious evidence and most common source of teaching of the view that marriage and other related institutions are not intrinsically religious. Such prescriptions are applied in most European and American countries, with the notable exception of Canada and the United States.

In Canada, until the answer by the Supreme Court to the Reference of the Governor General in Council on same-sex marriage in 2004, matrimony was constitutionally an intrinsically religious matter. In Quebec, as in the rest of Canada, religious marriage had and still has civil effects, which makes civil marriage largely irrelevant. In Quebec, until the 1990s, the only official certificate of identity a Catholic could get, even from civil authorities, was a copy of the baptismal certificate. If all of this were not enough to make it obvious to French-speaking Catholic Quebecers that marriage and birth were intrinsically religious matters, Catholic children were educated in Catholic schools, whether public or private, where they were taught that matrimony and baptism were sacraments and where they had very few opportunities to learn about laicization. Thus, when French-speaking Catholic Quebecers decided to stop following the moral teachings of the Catholic Church, they truly faced a void: they knew they wanted divorce and contraception to be morally right, but they suddenly lacked any intellectual foundation for such new moral norms.

As far as the authors know, what French-speaking Catholic Quebecers now use as the intellectual foundation of their moral thinking has not yet been seriously studied. A few facts make it clear that whatever intellectual foundation they use, they truly manage their family affairs outside the Christian tradition, whether in 
The Evolution of Beliefs and Opinions as Matters related to Marriage and Sexual Behaviour among French-speaking Catholic Quebecers and English-speaking Protestant Ontarions

its original form or laicized. We will limit our illustration of this to three areas: cohabitation, the legitimacy of children, and gender equality.

One of the striking and puzzling facts about cohabitation among Frenchspeaking Quebecers is that it has turned into an accepted and practical way of managing long-term as well as short-term relationships, and an accepted and practical way of raising a family. In very simple terms, this means that among French-speaking Quebecers, most of them of Catholic origin, the dominant belief is that the intervention of authorities, whether this means the State or the Churches, in the formation or dissolution of unions has little legitimacy, whether for rationalistic or religious motives. This is clear evidence of a very direct break from Christian tradition.

The civil law of most if not all Western nations has long implemented the notion that children born outside of wedlock were illegitimate, which basically meant that they had no inheritance rights. Provisions to this effect were repealed from the Quebec Civil Code in the 1980s. There is now no legal difference between children born from married or unmarried parents, whether the parents live together or not. Filiation is not conditional on marriage. Such a rule of filiation obviously facilitates the turning of cohabitation into a practical way of raising a family. Implementation of such a rule in civil law is, again, clear evidence of a very direct break from Christian tradition.

The Christian tradition has long been associated with the idea that women should yield to men, and French civil law was especially strict in its enforcement of this rule, even in its laicized version. Although gender equality is in no way a topic specific to Quebec, several scholars have noted that feminism has had more influence in Quebec than in other places, especially in the evolution of law and norms. In today's world, there is no foundation for the idea that women should yield to men, except in tradition. In the Western world, the religious beliefs of Christianity - if believed to be true and of supernatural origin, or if believed to follow from natural law, as in their laicized version-are the only intellectual foundation for the legal subjection of women. It is tempting to suggest that in a post-industrialized Western society where most people decided to abandon the Christian tradition as a moral guideline almost overnight, gender equality, as a legal and practical issue, should have moved forward more quickly than in comparable societies where Christian tradition remained a legitimate reference for legislators and courts of justice. If this interpretation of what happened in Quebec is correct, feminism would be an intermediate variable in the process that changed the opinions, norms and behaviour of French-speaking Quebecers. The big change would be the break from Christian tradition as a source of moral direction. 
Benoit Laplante, Caia Miller and Paskall Malherbe

Dagenais (2000) has proposed a somewhat related but very different interpretation of the transformation of family-related values, norms and behaviour in Quebec. He basically says that Quebecers have moved away from the modern form of the family as described by Parsons and Bales (1955) and are now living with a dysfunctional "post-modern" view of the family that does not ensure the reproduction of society because it does not lead to replacement level fertility and does not provide an appropriate environment for the socialization of children. We cannot fully discuss Dagenais' ideas here, but several comments are in order. First, most of his historical argumentation does not survive Thornton's (2005) synthesis, which makes it clear that the so-called modern Western family has existed at least since the 13th century. Second, Dagenais' analysis of the changes that occurred in family-related matters in Quebec says almost nothing about religious aspects and ignores contemporary research on the Quiet Revolution. And lastly, his assessment of current Quebec society is based on a never-stated but pervasive belief that the rationalized order of natural law and laicization, and the modern form of the family that is part of that order, are unsurpassable. Whether the current organization of society can support the reproduction of the species is not a new topic (e.g. Davis, 1997 [1937]); and there are reasons to believe that, without the clearly natalist provisions of Christianity or its laicized version, it is unclear why people, in the world we live in, would decide to have a child or to have more than one. We do not dispute that these questions are of utmost importance, but focusing on them does not help us to understand why and how beliefs, values and behaviours change over time and at a different pace in different societies.

This leads us to a discussion of whether the process we see among Frenchspeaking Catholic Quebecers can truly be considered as a somewhat accelerated form of the second demographic transition. As one of our reviewers pointed out, although some of the statistics we report in the introduction support the idea, one statistic definitely does not: that is, the fact that the current total fertility rates are similar in Quebec and Ontario. If the differences between Quebec and Ontario were to be accounted for by Quebec leading the way on the path of the second demographic transition as originally described by van de Kaa (1987), the total fertility rate should be lower in Quebec. Of course, one could argue that this might simply be a temporary situation, and that fertility should soon be dropping in Quebec. But it is also possible to imagine that, although the two processes are certainly related, the process that leads from traditional to non-traditional beliefs, norms and values relating to sex and the family and the process that determines fertility per se may be intrinsically different. The first process would be a consequence of the loss of legitimacy of the beliefs, norms and values inherited from Christianity, and of the will of the people to control such basic aspects of their lives as who they live with, in what way and for how long without having to ask any authorities' permission. The pace of this process in a 
The Evolution of Beliefs and Opinions as Matters related to Marriage and Sexual Behaviour among French-speaking Catholic Quebecers and English-speaking Protestant Ontarions

given society would largely depend on the importance of religion in this society and on the relation between the State and the Churches or other religious groups. The second process would be a consequence of the first-controlling one's fertility is contrary to the Christian tradition - to the extent that it gives men and women the power to decide whether or not they will have children. However, the actual decision to have children and how many would be largely driven by practical and contingent circumstances such as the cost of children, the relative importance of the woman's income in the family budget, the availability of child care, and so on. The more the first process is advanced, and thus the more fertility is the consequence of a choice, the more fertility would be influenced by practical and contingent circumstances.

\section{Acknowledgements:}

A preliminary version of this article was presented at the XXV IUSSP International Population Conference in Tours, France, on July 22, 2005. The authors wish to thank Dirk van de Kaa, who organized the session on the "Cultural dimensions of demographic behaviour in industrialized societies," for his support and comments. We are also grateful to the two reviewers whose comments helped us to write a better article and greatly enriched the discussion.

\section{References:}

Baum, Gregory. 1990. "Le rapport Dumont. Démocratiser l'Église catholique," Sociologie et sociétés, 22 (2): 115-126.

Beaujot, Roderic. 2000. "Les deux transitions démographiques du Québec, 1860-1996," Cahiers québécois de démographie, 29: 201-230.

Bélanger, Alain and Pierre Turcotte. 1999. "L'influence des caractéristiques sociodémographiques sur le début de la vie conjugale des Québécoises," Cahiers québécois de démographie, 28: 173-197.

Bibby, Reginald W. 1987. Fragmented Gods: The Poverty and Potential of Religion in Canada. Toronto: Irwin Publishing.

Bibby, Reginald W. 2002. Restless Gods: The Renaissance of Religion in Canada. Toronto: Stoddart Publishing. 
Benoit Laplante, Caia Miller and Paskall Malherbe

Dagenais, Daniel. 2000. La fin de la famille moderne : la signification des transformations contemporaines de la famille. Sainte-Foy: Presses de l’Université Laval.

Davis, Kingsley. 1997 [1937]. "Kingsley Davis on Reproductive Institutions and the Pressure for Population," Population and Development Review, 23: 611-624.

Gallup, George and Michael Lindsay. 1999. Surveying the Religious Landscape. Harrisburg: Morehouse Publishing.

Gauvreau, Michael. 2005. The Catholic Origins of Quebec's Quiet Revolution, 1931-1970. Montreal, Kingston: McGill-Queen's University Press.

Hoem, Britta and Jan M. Hoem. 1988. "The Swedish Family. Aspects of contemporary developments," Journal of Family Issues, 9: 397-424.

Kerr, Don, Melissa Moyser and Roderic Beaujot. 2006. "Marriage and Cohabitation: Demographic and Socioeconomic Differences in Quebec and Canada," Canadian Studies in Population, 33: 83-109.

Kiernan, Kathleen. 2000. "European perspectives on union formation," in Linda J. Waite (ed.), The Ties that Bind. Perspectives on Cohabitation and Marriage (p. 40-58). New York: Aldine de Gruyter.

Kiernan, Kathleen. 2002. "Cohabitation in Western Europe. Trends, issues and implications," in Alann Booth and Ann C. Crouter (eds.), Just Living Together. Implications of Cohabitation on Families, Children, and Social Policy (p. 3-31). Mahwah NJ: Lawrence Erlbaum.

Kitchin, Shepherd B. 2002 [1912]. A History of Divorce. Union NJ: Lawbook Exchange.

Lapierre-Adamcyk, Évelyne, Céline Le Bourdais and Nicole Marcil-Gratton. 1999. "Vivre en couple pour la première fois. La signification du choix de l'union libre au Québec et en Ontario," Cahiers québécois de démographie, 28 (1-2): 199-227.

Laplante, Benoît. 2006. "The rise of cohabitation in Quebec. Power of religion and power over religion," Canadian Journal of Sociology, 31 (1): 1-24. 
The Evolution of Beliefs and Opinions as Matters related to Marriage and Sexual Behaviour among French-speaking Catholic Quebecers and English-speaking Protestant Ontarions

Le Bourdais, Céline and Nicole Marcil-Gratton. 1996. "Family transformations across the Canadian/American border: When the laggard becomes the leader," Journal of Comparative Family Studies, 27: 415-436.

Mahoney, John. 1987. The Making of Theology. Oxford UK: Clarendon Press.

Meunier, E.-Marin and Jean-Philippe Warren. 2002. Sortir de la « Grande Noirceur ». Sillery: Éditions du Septentrion.

Noonan, John T. Jr. 1965. Contraception. A history of its treatment by the Catholic theologians and canonists. Cambridge MA: Belknap Press/Harvard University Press.

Oppenheimer, Valerie Kincade. 1994. "Women's rising employment and the future of the family in industrial societies," Population and Development Review, 20: 293-342.

Oppenheimer, Valerie Kincadee, Matthijs Kalmijn and Nelson Lim. 1997. "Men's career development and marriage timing during a period of rising inequality," Demography, 34: 311-330.

Parsons, Talcott and Robert F. Bales. 1955. Family, Socializatio and Interaction Process. New York NY: The Free Press.

Phillips, Roderick.1988. Putting Asunder: A History of Divorce in the Western Society. New York NY: Cambridge University Press.

Prinz, Christopher. 1995. Cohabiting, Married, or Single. Aldershot UK: Avebury.

Ratzinger, Joseph. 1987. Principles of Catholic Theology. Building Stones for a Fundamental Theology. San Francisco CA: Ignatius Press.

Ravanera, Zenaida R., Fernando Rajulton and Thomas K. Burch. 1998. "Early Life Transitions of Canadian Women: A Cohort Analysis of Timing, Sequences, and Variations," European Journal of Population, 14 (2): 179-204.

Thornton, Arland. 2005. Reading History Sideways: The Fallacy and Enduring Impact of the Developmental Paradigm on Family Life. Chicago: The University of Chicago Press. 
Benoit Laplante, Caia Miller and Paskall Malherbe

van de Kaa, Dirk J. 1987. "Europe's second demographic transition,"

Population Bulletin, 42 (1): 1-59.

Warren, Jean-Philippe and E. Marin Meunier. 1999. "L'horizon 'personnaliste' de la révolution tranquille," Société, 20-21:347-448.

Wu, Zheng. 2000. Cohabitation. An Alternative Form of Family Living. Don Mills ON: Oxford University Press. 